\title{
The distribution of ciliates on Ecology Glacier (King George Island, Antarctica): relationships between species assemblages and environmental parameters
}

\author{
Tomasz Mieczan • Dorota Górniak • \\ Aleksander Świątecki • Marek Zdanowski • \\ Monika Tarkowska-Kukuryk
}

Received: 16 May 2012/Revised: 11 October 2012/Accepted: 17 October 2012/Published online: 17 November 2012

(C) The Author(s) 2012. This article is published with open access at Springerlink.com

\begin{abstract}
Ciliates are important consumers of pico- and nano-sized producers, are nutrient regenerators, and are an important food source for metazoans. To date, ecological research on ciliates has focused on marine ecosystems rather than on glacier habitats. This paper presents the first major study on ciliates from the Ecology Glacier (South Shetland Islands, Antarctica). The objective of the study was to investigate the structure and spatial distribution of ciliate communities and to identify the environmental factors determining the structure of the assemblages. Microbial communities were collected from three habitats: surface snow, cryoconite holes, and glacier streams. Sampling was carried out every 3-4 days from January 17 to February 24, 2012. A total of 18 ciliate taxa were identified. The species richness, abundance, and biomass of protozoa differed significantly between the stations studied with the lowest numbers in streams on the glacier surface and the highest numbers in cryoconite holes. The RDA performed to specify the direct relationships between the abundance of ciliate taxa and environmental variables showed obvious differences between studied habitats. The analysis showed that all variables together explained $62.4 \%$ of total variance. However, variables that
\end{abstract}

T. Mieczan $(\bowtie) \cdot$ M. Tarkowska-Kukuryk

Department of Hydrobiology, University of Life Sciences,

Dobrzańskiego 37, 20-262 Lublin, Poland

e-mail: tomasz.mieczan@up.lublin.p1

D. Górniak · A. Świątecki

Department of Microbiology, University of Warmia and Mazury,

Oczapowskiego 1A, 10-719 Olsztyn, Poland

M. Zdanowski

Department of Antarctic Biology, Institute of Biochemistry

and Biophysics, Polish Academy of Sciences,

Ustrzycka 10/12, 02-141 Warsaw, Poland significantly explained the variance in ciliate communities in cryoconite holes, snow, and surface streams were temperature, conductivity, and total nitrogen. Further research is required to explain the impact of biotic factors influencing the presence of ciliates, including the abundance of bacteria, microalgae, and small Metazoa.

Keywords Ciliates · Glaciers · Cryoconite holes · Antarctica

\section{Introduction}

Glaciers and ice sheets are among the least explored sectors of the Earth's biosphere. The existence of glaciers and ice sheets is determined by particular patterns of precipitation, temperature, and topographic conditions. Glaciers are characterized by low temperatures associated with the accumulation of snow and/or water as ice in the accumulation zone in winter, and the removal of ice in summer by melting, sublimation, and calving in the ablation zone (Anesio and Laybourn-Parry 2012). Glacial surfaces are exposed to large amounts of fine wind-blown particles that are cemented into aggregates by microbial exudates. The resulting dark particles melt into the ice and form cryoconite holes, water-filled depressions (typically $5 \mathrm{~cm}-<1 \mathrm{~m}$ in diameter and $<0.5 \mathrm{~m}$ deep) that develop on glaciers when solar-heated inorganic and organic debris melt into the surface. There is increasing evidence from clone libraries and microscopy studies that a highly abundant microbial community can be found in cryoconite holes, including viruses, bacteria, and algae (Mueller et al. 2001; Porazinska et al. 2004; Anesio et al. 2007), and other organisms such as tardigrades, rotifers, nematodes, protozoa, and insect larvae (Koshima 1984; Grongaard et al. 1999). Recent investigations suggest 
that glaciers are neither sterile nor abiotic repositories of dormant cells. In fact, they support a large number of active microbial communities (Anesio et al. 2007, 2009) and are distinguished by rich biodiversity. Glaciers are therefore important for preserving the stability of ecological relationships in polar area but are among the fastest disappearing and most endangered ecosystems in the world (Oerlemans 1986). This is of particular concern in combination with progressive climate warming (Säwström et al. 2002). Previous studies on the structure and function of glacier ecology have focused on bacterial communities (Anesio et al. 2009), and very little is known about ciliates and their role in these ecosystems. In the taxonomical approach to the ecology of algae, rotifers and tardigrades are usually studied independently, and the focus has been on the taxonomy of the species restricted to glaciers (Anesio et al. 2009). In contrast, little or no attention has been given to the abundance and trophic structure of ciliates. These microorganisms are important consumers of pico- and nano-sized producers, are nutrient regenerators, and are an important food source for metazoans (Pierce and Turner 1992). Säwström et al. (2002) studied ciliates in cryoconite holes in Antarctica, and the ubiquitous Monodinium, Halteria, and Strombidium dominated the genera identified. Other researchers identified sphagnophilus and soil protozoa (Foissner 1996; Petz 1997; Bamforth et al. 2005). However, the majority of ecological research on ciliates has focused on lake and marine ecosystems rather than on glacier habitats (Laybourn-Parry et al. 1991; Roberts et al. 2004). These studies showed that water temperature and nutrients were positively correlated with the density and biomass of ciliates. However, no similar investigations have been carried out on glaciers. One of the primary goals of the present study was to identify the taxonomic composition and trophic structure of ciliates occurring in cryoconite holes, streams, and surface snow on glaciers. As reported by Wharton et al. (1981), glacier ecosystems are distinguished by a particular microtopography that results in a lengthwise gradation of bacterial distribution. Similar findings could be expected for the distribution of ciliates. In summary, the research was undertaken to verify the following hypotheses: (1) that the physio-chemical characteristics of water influence the species structure of ciliates on glaciers and (2) that species richness and abundance show distinct differentiation at various sites (cryoconite holes, ephemeral streams, and snow).

\section{Materials and methods}

Study site

Samples were collected from Ecology Glacier, part of the Warszawa Icefield, located on King George Island (South
Shetland Islands, Antarctic Peninsula, $62^{\circ} 10^{\prime} \mathrm{S}, 58^{\circ} 28^{\prime} \mathrm{W}$ ) (Fig. 1). Approximately $94 \%$ of the island is covered with ice and the highest point of the ice cap extends to about $650 \mathrm{~m}$ above sea level. The island's climate is characterized by a rapid succession of eastward moving low-pressure systems that transport relatively warm, humid air toward the coast of Antarctica (Bintanja 1995). These systems explain the relatively high annual mean temperature $\left(2.0^{\circ} \mathrm{C}\right)$ and humidity level $(82 \%)$ at Arctowski Station, situated on the south-eastern side of the island (Martinov and Rakusa-Suszczewski 1989). During summer, the mean temperature is well above zero and precipitation varies from $500 \mathrm{~mm} \mathrm{year}^{-1}$ at sea level to approximately $2,000 \mathrm{~mm} \mathrm{year}^{-1}$ at the summit of the island (Martinov and Rakusa-Suszczewski 1989). During the past decade, a rapid retreat of valley-type tidewater glaciers has been observed. Birkenmajer (2002) described the Ecology Glacier retreat in detail. It has been under continuous recession since at least 1956 , but the rate of

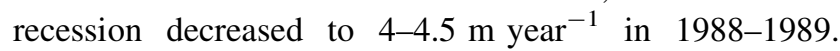
However, it rapidly accelerated in the decade from 1989 to 1999, reaching a rate of up to $30 \mathrm{~m} \mathrm{year}^{-1}$ (Gryziak 2009).

Sampling and laboratory analyses

A transect was established running up the ablation zone of the Ecology Glacier, and two additional samples were taken from the medial edges of the glacier, approximately half way along the transect. Microbial communities were sampled from three habitat types: surface snow $\left(62^{\circ} 10.370^{\prime} \mathrm{S}, 58^{\circ} 28.567^{\prime} \mathrm{W}, 80 \mathrm{~m}\right.$ a. s. 1.), cryoconite holes $\left(62^{\circ} 10.404^{\prime} \mathrm{S}, 58^{\circ} 28.546^{\prime} \mathrm{W}, 85-145 \mathrm{~m}\right.$ a. s. 1.), and glacier streams $\left(62^{\circ} 10.226^{\prime} \mathrm{S}, 58^{\circ} 28.268^{\prime} \mathrm{W}, 40 \mathrm{~m}\right.$ a. s. 1.). Surface snow, cryoconite, and stream water and sediment were sampled from a zone in the mid-parts of the ablation area at around 80-145 m altitude. Additionally, two surface snow samples were taken from an accumulation zone $\left(62^{\circ} 10.474^{\prime} \mathrm{S}, 58^{\circ} 29.288^{\prime} \mathrm{W},>230 \mathrm{~m}\right.$ a. s. 1.). Sampling was carried out every three to 4 days from January 17 to February 24, 2012. During each sampling session, three samples were collected from each site (surface snow-8 sites, cryoconite holes -8 sites, glacier streams -8 sites). Samples from the upper $1-5 \mathrm{~cm}$ of snow were collected using a plastic tube (diameter $=50 \mathrm{~mm}, \sim 30 \mathrm{ml}$ water volume). Cryoconite and stream sediment and water were sampled using a plastic pipette (diameter $=50 \mathrm{~mm}$ ). The volume of sediment and water extracted from each habitat ranged from 10 to $15 \mathrm{ml}$. Three subsamples, about $10 \mathrm{ml}$ each, were pooled into a calibrated vessel to form a composite sample $(30 \mathrm{ml})$. Quantitative sampling and counting were performed with classical limnological methods using the Utermöhl technique (Utermölh 1958). The first subsample was retained for live analysis; then, $20 \mathrm{ml}$ of 
Fig. 1 Location of King

George Island (a) and Ecology Glacier (b) with the sampling sites

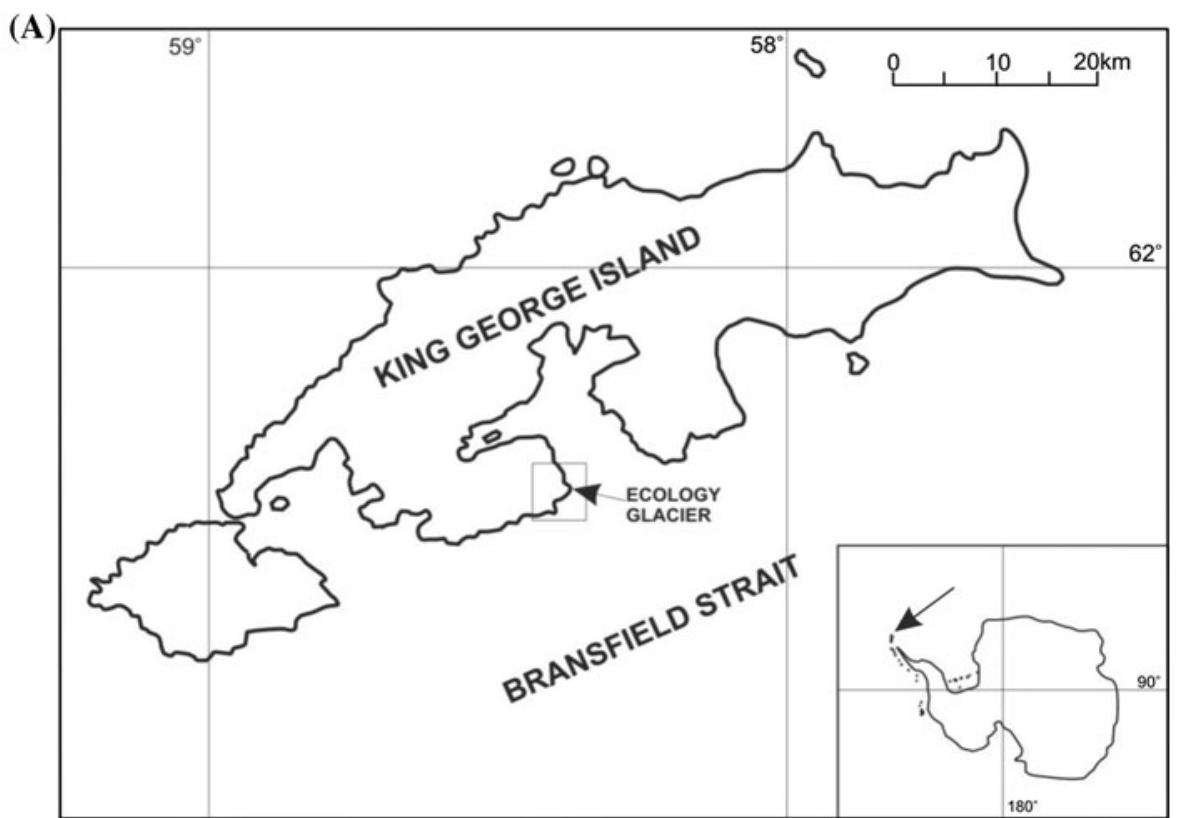

(B)

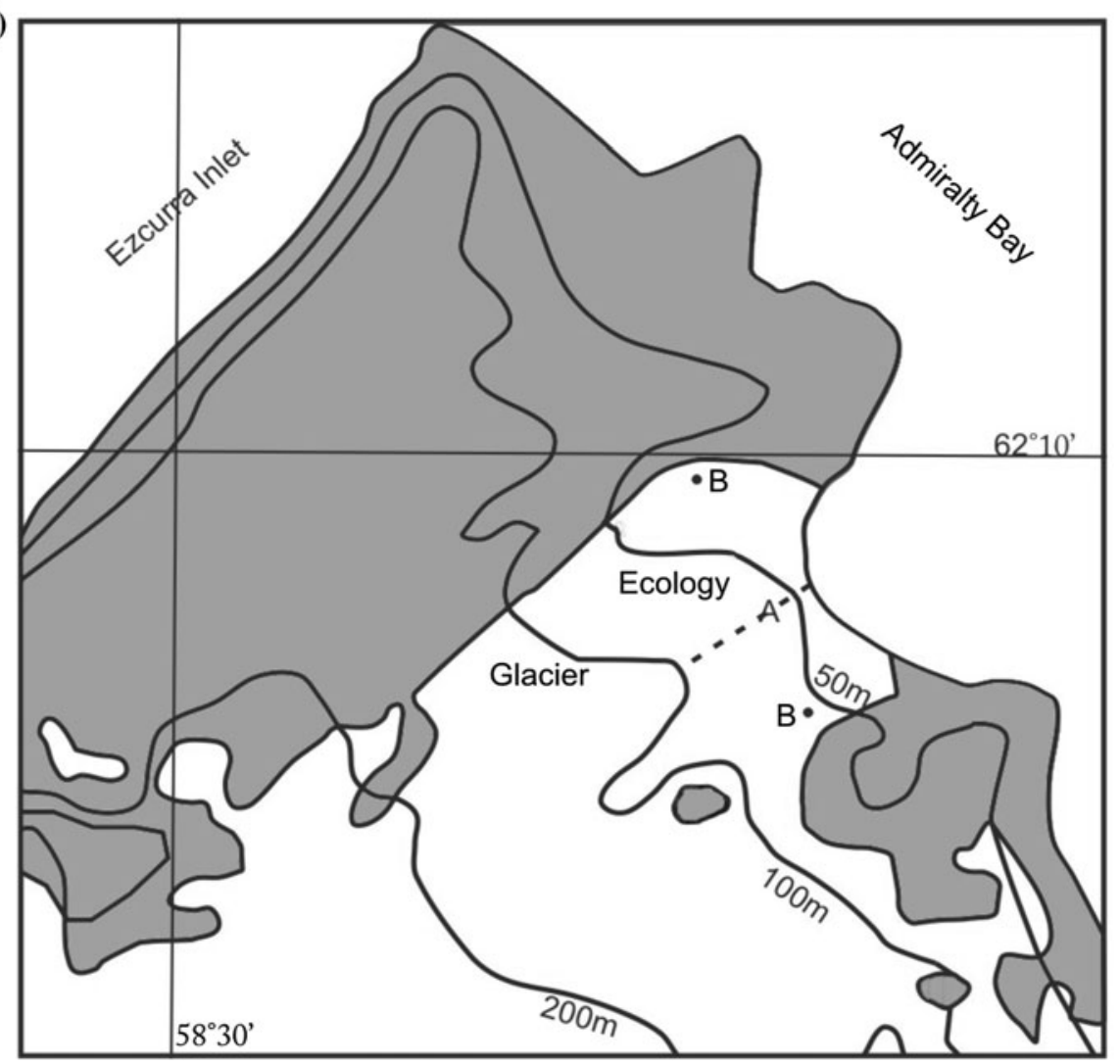

water was immediately preserved with Lugol's solution ( $0.2 \%$ final concentration), settled in a glass column for $24 \mathrm{~h}$ in the laboratory, and then concentrated to $10 \mathrm{ml}$. Finally, organisms in $0.1 \mathrm{ml}$ of the concentrated sample were counted using a Nikon Eclipse microscope with phase contrast at 400-1,000 $\times$ magnification. Estimates of ciliates abundance were obtained by enumerating specimens in 300 randomly selected microscope fields. Cell sizes were measured on 10 specimens of each species using a camera (5 Mega pixel) attached to the microscope. The abundance of microorganisms was calculated per $1 \mathrm{ml}$ of water. Ciliates are highly perishable, and their motility is a species-specific feature; therefore, species identification and measurements were made on live material immediately 
after returning to the laboratory and after silver impregnation (Augustin et al. 1984). Live ciliate samples were analyzed in a $1 \mathrm{ml}$ Sedgwick-Rafter counting cell under a binocular microscope, and subsamples of dense samples were taken with a Hensen-Stempel pipette. The species were identified using the following methods: intravitalcoloring vacuoles with indifferent red (can color the macronucleus) and the micro- and macronucleus with malachite green (Lee et al. 1985), and the Fernandez-Galiano method-coloring the cell structures in ammoniacal solution (kinetosomes, the micro- and macronucleus) (Fernandez-Galiano 1994). Trophic identification was performed following the method of Foissner and Berger (1996).

Ciliate biomass was estimated by multiplying the numerical abundance by the mean cell volume $\left(1 \mu \mathrm{m}^{3}=\right.$ $1 \mathrm{pg}$ ) calculated from direct volume measurements using appropriate geometric formulas (Finlay 1982). Biovolumes of ciliates were estimated by assuming geometric shapes and converting to carbon using the following conversion factor: $1 \mu \mathrm{m}^{3}=1.1 \times 10^{-7} \mu \mathrm{g} \mathrm{C}$ (Gilbert et al. 1998). An obvious shrinkage of stained ciliates was noticed with the silver preparation. Therefore, calculated cell volumes were multiplied by a correction factor of 0.4 (Jerome et al. 1993). The Gini evenness index was calculated because its independence of the number of taxa per sample allowed a better comparison between samples (Nijssen et al. 1998).

The frequency of occurrence of single species was calculated as a percentage of all collected samples in which the species was noted. All species were classified into four groups as follows: very constant species (occurring in 61-100\% of samples), constant species (occurring in $41-60 \%$ of samples), accidental species (occurring in $21-40 \%$ of samples), and accessory species (occurring in $<20 \%$ of samples).

The similarity of ciliates between the zones was evaluated using Jaccard's method:

$\mathrm{S}_{x y}=\frac{c}{a+b-c} \times 100 \%$

where $S_{x y}$ is the faunistic similarity between data sets $x$ and $y, c$ is the number of taxa common for sets $x$ and $y, a$ is the number of taxa in set $x$, and $b$ is the number of taxa in set $y$.

Surface snow and water samples for chemical analysis were taken simultaneously with microbial samples. Temperature, oxygen, $\mathrm{pH}$, and conductivity were determined in situ using a multifunction device equipped with an integrated head (CX-461, Elmetron, Poland). The remaining factors (total nitrogen $N_{\text {tot }}$, total phosphorus $P_{\text {tot }}$, ammonium nitrogen $\mathrm{N}-\mathrm{NH}_{4}$, and dissolved orthophosphates $\mathrm{P}-\mathrm{PO}_{4}$ ) were analyzed in the laboratory using a spectrophotometer VEGA 400 equipped with a thermoreactor (Spectroquant TR320, Merck, Germany). Concentrations of total phosphorous and dissolved orthophosphates were determined using a spectrophotometric method with ammonium heptamolybdate, and concentrations of ammonium nitrogen and total nitrogen were determined using Kjeldahl's method (Golterman 1969).

\section{Statistical analyses}

Diversity analysis (Shannon-Wiener diversity index, $\log _{10^{-}}$ based) was performed using the Multivariate Statistical Package MVSP (2002, Kovach Computing Services). All statistical analyses were made using SAS (2001). All abiotic and biotic data were log-transformed to approximate a normal distribution and to linearize bivariate relationships. Full-factorial ANOVA was used to test for significant effects of the three independent factors (type of micro-site, vertical micro-distribution, and time) on ciliate species richness and abundance. Ordination techniques were used to describe the relationships between the abundance of ciliates in different habitats (cryoconite holes, snow, and surface streams) and environmental variables. An indirect multivariate method, DCA, was used to measure and illustrate gradients indicated by ciliate communities. Because the length of the gradient was $<3$ standard deviations, redundancy analysis (RDA) was used to explore the relationship between the abundance of ciliate taxa and physical and chemical variables (Ter Braak 1988-1992). Principal Component Analysis (PCA) was performed to confirm the separation of ciliate communities among cryoconite holes, snow, and surface stream habitats. The analysis was performed based on the abundance of ciliate species. Automatic forward selection of environmental variables (Monte Carlo permutation test) was used to determine the most important variables (Lepš and Šmilauer 2003). Variables for which the level of significance did not exceed 0.05 were marked actively on the diagrams. The ordination analyses were performed using CANOCO 4.5 for Windows.

\section{Results}

\section{Environmental variables}

The water temperature varied among sites and samples, ranging from $-0.05{ }^{\circ} \mathrm{C}$ in cryoconite holes and surface streams to $-0.72{ }^{\circ} \mathrm{C}$ in surface snow (ANOVA, $F=16.5$, $p=0.001$ ). Statistically significant differences among the studied habitats were found for $\mathrm{pH}$, conductivity, $P_{\text {tot }}, N_{\text {tot }}$, $\mathrm{N}-\mathrm{NH}_{4}$, and $\mathrm{P}_{-} \mathrm{PO}_{4}$ (ANOVA, $F=14.21-16.22, p=$ 0.001). Among the studied habitats, the highest average $\mathrm{pH}$ value ( $\mathrm{pH} 8.45$ ) was noted in the cryoconite holes and the lowest in the surface snow ( $\mathrm{pH}$ 6.55). Concentrations of $P_{\text {tot }}$ and $\mathrm{P}_{-} \mathrm{PO}_{4}$ were highest in the surface streams; 
however, the remaining parameters (conductivity, $N_{\text {tot }}$, and $\mathrm{N}-\mathrm{NH}_{4}$ ) showed highest values in the cryoconite holes (Table 1).

Ciliate species richness and abundance

A total of 18 ciliate taxa were identified (Table 2). The highest number of ciliate taxa (18) occurred in the cryoconite holes. Lower numbers of taxa (8) were observed in the surface streams. The diversity analysis revealed a mean Shannon-Wiener diversity index of $0.92 \pm 0.05$ and a Gini evenness measure of $0.39 \pm 0.01$. The highest diversity was measured in the cryoconite holes $\left(H^{\prime}=1.23\right)$, and the lowest diversity was observed in the streams $\left(H^{\prime}=0.03\right)$. The mean number of taxa per sample was $6 \pm 1$, with a maximum of 15 taxa per sample in cryoconite holes and a minimum of 2 taxa in streams. Jaccard's index of similarity ranged from 50 to $65 \%$. The group of characteristic (exclusive) taxa that occurred only in one habitat was comparatively small. The exclusive species in cryoconite holes were Codonella cratera, Drepamonas revoluta, Urotricha sp., and Zosterodasys sp. The most frequent taxa were Prorodon sp., Oxytricha sp., and Holophrya sp., and 6 ciliate taxa had frequencies $<5 \%$. In surface snow, only Holophrya sp. was a very constant species, and two species, Colpoda cucullus and Paramecium putrinum, were accidental species. The remaining 6 species were accessory species. In cryoconite holes Cyrtophorida, Cinetochilum margaritaceum, C. cucullus, Euplotes sp., Prorodon sp., Oxytricha sp., and Caenomorpha spp. occurred as very constant species. One taxon, Holosticha pullaster, was a constant species. There were also 5 accessory and 5 accidental species. Three species, Caenomorpha spp., Halteria sp., and Stylonychia mytilus-Komplex were very constant in the streams. The further 2 taxa found, Amphileptus pleurosigma and $P$. putrinum, were constant species, 1 species was an accidental species, and 2 were accessory species (Table 2). The ciliate abundances were also significantly related to the type of micro-habitat, with the lowest numbers in the surface streams $\left(6 \pm 2\right.$ ind. $\left.\mathrm{ml}^{-1}\right)$ and the highest in the cryoconite holes $\left(21 \pm 6\right.$ ind. $\left.\mathrm{ml}^{-1}\right)$ (ANOVA, $F=18.5, p=0.001$ ). Ciliate biomass, corresponding with abundances, was significantly higher in the cryoconite holes $\left(73 \pm 11 \mu \mathrm{g} \mathrm{C} \mathrm{ml}^{-1}\right)$ than in streams $\left(34 \pm 7 \mu \mathrm{g} \mathrm{C} \mathrm{ml}^{-1}\right.$ ) (ANOVA, $\left.F=21.2, p=0.001\right)$. The community composition of ciliates varied greatly between micro-habitats. Holophrya sp. and Prorodon sp. dominated in the surface snow, while Oxytricha sp., Prorodon sp., C. cucullus, and Cyrtophorida were prevalent in the cryoconite holes. In ephemeral streams, the community was predominantly composed of Caenomorpha spp., S. mytilus-Komplex, and Halteria gradinella (Fig. 2).

Size classes and feeding groups

Overall, medium-sized ciliates (50-200 $\mu \mathrm{m})$ dominated all sampling dates and sites combined, accounting for up to $50-65 \%$ of the total. Small species $(<50 \mu \mathrm{m})$ represented $10-40 \%$, and large ciliates $(>200 \mu \mathrm{m})$ made up 10-23\% of the samples (Fig. 3). However, the class size of ciliates differed clearly between micro-habitats. Medium-sized forms dominated cryoconite holes and surface snow, while the remaining micro-habitats were dominated by small ciliates. Ciliate feeding groups consisted of bacterivores, algivores, algae-diatom feeders, mixotrophic predators, and omnivores (Table 2). Bacterivore taxa clearly dominated in cryoconite holes $(>40 \%)$, while surface snow and streams were dominated by omnivorous ciliates (50-58\% of the total number) (Fig. 4).

Relationships between ciliate communities and environmental variables

In the PCA diagram (Fig. 5 a, b), the first two axes separate ciliate communities among studied habitats. Axis 1 $(\lambda=0.510)$ and axis $2(\lambda=0.221)$ explained $73.1 \%$ of the total variance in the ciliate data. The abundance of ciliates was most strongly correlated with the main direction of variation (axis 1), with samples collected in cryoconite holes (Fig. 5a). The densities of most ciliate taxa increased toward cryoconite habitats (Fig. 5b). Axis 2 appeared to separate ciliate communities collected in cryoconite holes from snow and surface stream habitats.

The RDA performed to specify the direct relationships between the abundance of ciliate taxa and environmental

Table 1 Physical and chemical characteristics of the water of investigated glacier (average values January-February 2012)

\begin{tabular}{|c|c|c|c|c|c|c|c|c|}
\hline Habitats & $\begin{array}{l}\text { Temp. } \\
\left({ }^{\circ} \mathrm{C}\right)\end{array}$ & $\begin{array}{l}\text { Cond. } \\
\left(\mu \mathrm{sm}^{-1}\right)\end{array}$ & $\mathrm{pH}$ & $\begin{array}{l}\text { Dissolv. oxygen } \\
\left(\mathrm{mg}^{-1}\right)\end{array}$ & $\begin{array}{l}N_{\text {tot }} \\
\left(\mathrm{mg} \mathrm{N}^{-1}\right)\end{array}$ & $\begin{array}{l}\mathrm{N}-\mathrm{NH}_{4} \\
\left(\mathrm{mg} \mathrm{N}^{-1}\right)\end{array}$ & $\begin{array}{l}P_{\text {tot }} \\
\left(\mathrm{mg} \mathrm{P}^{-1}\right)\end{array}$ & $\begin{array}{l}\mathrm{P}_{-} \mathrm{PO}_{4} * \\
\left(\mathrm{mg} \mathrm{PO}_{4}{ }^{3-} 1^{-1}\right)\end{array}$ \\
\hline Surface snow & -0.72 & 0.51 & 6.55 & 8.80 & 0.625 & 0.024 & 0.03 & 0.170 \\
\hline Cryoconite holes & -0.05 & 2.49 & 8.45 & 11.45 & 1.451 & 0.085 & 0.13 & 0.232 \\
\hline Surface streams & -0.05 & 1.95 & 8.27 & 11.17 & 0.810 & 0.077 & 0.22 & 0.325 \\
\hline
\end{tabular}

* Temp. Temperature, Cond. conductivity, Dissolv. oxygen dissolved oxygen, $\mathrm{N}_{\text {tot }}$ total nitrogen, $\mathrm{N}_{-} \mathrm{NH}_{4}$ ammonium nitrogen, $P_{\text {tot }}$ total phosphorus, $\mathrm{P}_{-} \mathrm{PO}_{4}$ dissolved orthophosphates 
Table 2 The composition and frequence (\% of samples) of ciliates taxa found on Ecology Glacier

* Main food explanation: $A$ algivores, $A l$ algae-diatom feeders, $B$ bacterivores, $M$ mixotrophic, $O$ omnivores, $P$ predators (Foissner and Berger 1996)

Fig. 2 Domination structure of ciliates in investigated habitats on Ecology Glacier (\% of total numbers)

\begin{tabular}{|c|c|c|c|c|c|}
\hline \multirow[t]{2}{*}{ Taxon } & \multirow[t]{2}{*}{ Size $(\mu \mathrm{m})$} & \multirow[t]{2}{*}{ Main food* } & \multicolumn{3}{|c|}{ Habitat type } \\
\hline & & & Snow & $\begin{array}{l}\text { Cryoconite } \\
\text { holes }\end{array}$ & Streams \\
\hline A. pleurosigma (Stokes 1884) & $>200$ & $\mathrm{P}$ & 0 & 10 & 50 \\
\hline Cyrtophorida & $>50$ & B & 10 & 100 & 0 \\
\hline C. margaritaceum (Ehrenberg 1831) & $<50$ & $\mathrm{~B}, \mathrm{~A}$ & 0 & 61 & 0 \\
\hline C. cratera (Leidy 1877) & $>50$ & A & 10 & 10 & 0 \\
\hline C. cucullus (Muller 1773) & $>50$ & $\mathrm{O}$ & 30 & 100 & 0 \\
\hline Caenomorpha spp. & $>50$ & B & 0 & 100 & 100 \\
\hline Drepanomonas rezoluta (Pennard 1922) & $<50$ & B & 0 & 30 & 0 \\
\hline Euplotes sp. & $>50$ & $\mathrm{O}$ & 10 & 61 & 30 \\
\hline Halteria sp. & $<50$ & $\mathrm{~B}, \mathrm{~A}$ & 0 & 10 & 80 \\
\hline Holophrya sp. & $>50$ & $\mathrm{O}$ & 100 & 50 & 0 \\
\hline H. pullaster (Mueller 1773) & $>50$ & $\mathrm{~B}, \mathrm{Al}$ & 10 & 10 & 0 \\
\hline Oxytricha sp. & $>50$ & $\mathrm{O}$ & 10 & 100 & 10 \\
\hline P. putrinum (Claparade, Lachmann 1859) & $>50$ & $\mathrm{O}$ & 10 & 30 & 50 \\
\hline Prorodon sp. & $>200$ & $\mathrm{P}$ & 30 & 90 & 0 \\
\hline S. mytilus-Komplex & $>200$ & $\mathrm{O}$ & 0 & 30 & 80 \\
\hline Vorticella companula (Ehrenberg 1831) & $>50$ & $\mathrm{~B}, \mathrm{~A}$ & 0 & 10 & 10 \\
\hline Urotricha sp. & $<50$ & $\mathrm{~B}, \mathrm{~A}$ & 0 & 40 & 0 \\
\hline Zosterodasys sp. & $>200$ & $\mathrm{Al}$ & 0 & 40 & 0 \\
\hline Total species number: 18 & & & 9 & 18 & 8 \\
\hline
\end{tabular}

variables showed obvious differences between studied habitats. All variables together explained $62.4 \%$ of total variance. However, variables that significantly $(p<0.05$, Monte Carlo permutation test) explained the variance in ciliate communities in cryoconite holes, snow, and surface streams were temperature $(\lambda=10.11, F=4.11, p=$ $0.008), N_{\text {tot }}(\lambda=60.13, F=4.19, p=0.002)$, and conductivity $(\lambda=20.30, F=8.10, p=0.002)$. The RDA biplot showed a direct influence of habitat on ciliate communities (Fig. 6a, b). Axis 1 appeared to separate ciliate taxa collected in cryoconite holes from those found in snow and surface streams.

\section{Discussion}

A total of 18 ciliate taxa were recorded on the Ecology Glacier. The highest number of taxa (18) was recorded in cryoconite holes and the least (8) in surface ephemeral streams. In contrast, on a glacier in the Arctic archipelago 


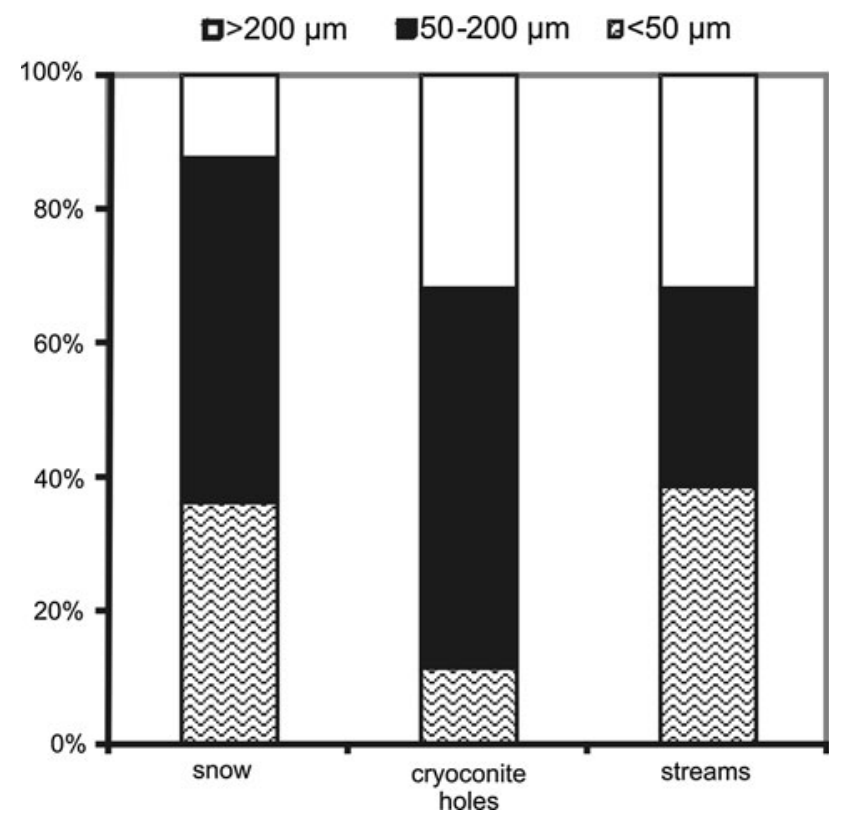

Fig. 3 Percentages of the dominant size classes for ciliates in investigated habitats on Ecology Glacier

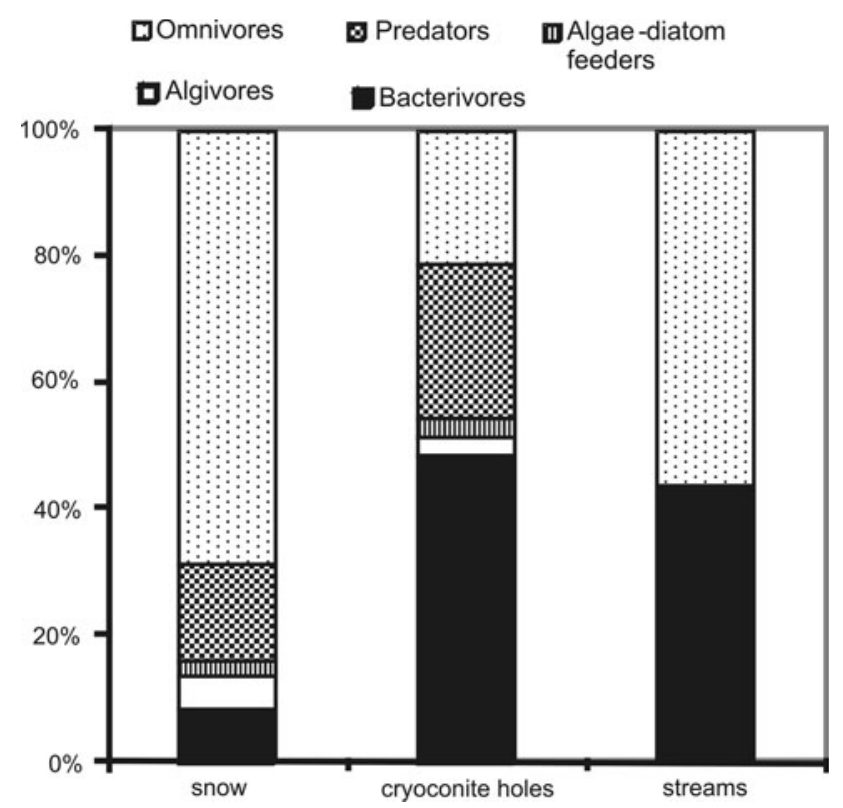

Fig. 4 Percentages of dominant feeding groups for ciliates in investigated habitats on Ecology Glacier

of Svalbard, in micro-sites dominated by cryoconite holes, only four species of ciliates were observed (Säwström et al. 2002). To date, no data are available on the comparison of ciliates in other micro-habitats on glacier surfaces. The number of species of ciliates increased with an augmentation in the concentration of nutrients. Similar results were obtained in Antarctic lakes (Roberts et al. 2004). The present study revealed a significant relationship between ciliate species richness and the type of micro-environment.
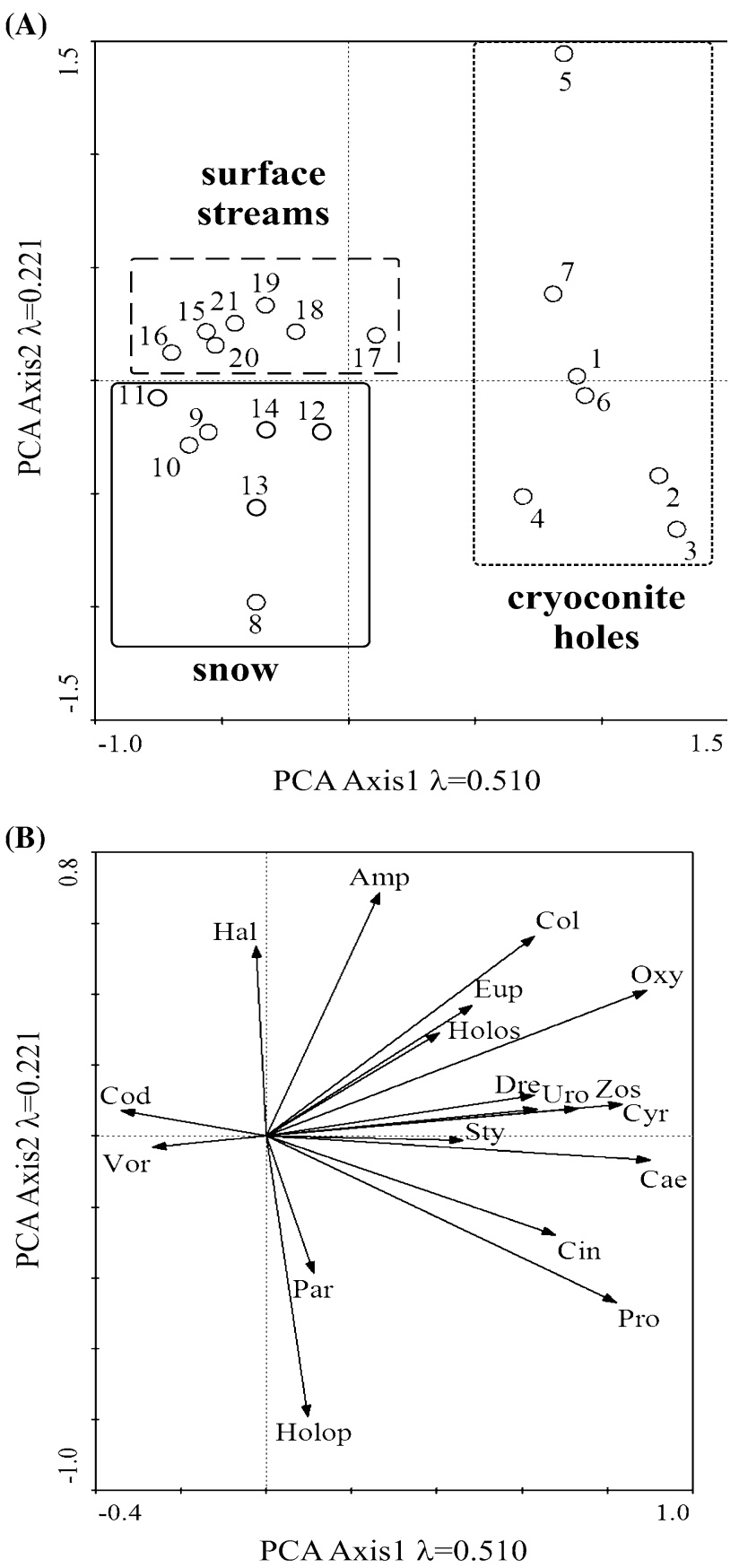

Fig. 5 Principal components analysis (PCA) biplots for Axes 1 and 2 showing: a study sites, $\mathbf{b}$ ciliates community. Axes are derived from the variation in the taxonomic data-matrix. Samples collected in studied sites are marked with an Arabic numeral: 1-7 cryoconite holes; 8-14 snow; 15-21 surface streams (Amp-A. pleurosigma, Cyr-Cyrtophorida, Cin-C. margaritaceum, Cod-C. cratera, Col-C. cucullus, Cae-Caenomorpha spp., Dre-Drepanomonas revolute, Eup—Euplotes sp., Hal—Halteria sp., Hol—Holophrya sp., Holos-H. pullaster, Oxy-Oxytricha sp., Par-P. putrinum, ProProrodon sp., Sty-S. mytilus-Komplex, Vor-V. companula, UroUrotricha sp., Zos-Zosterodasys sp.)

Significantly higher numbers of species were observed in cryoconite holes than in surface snow and streams. Cameron et al. (2011) observed a clear increase in the 

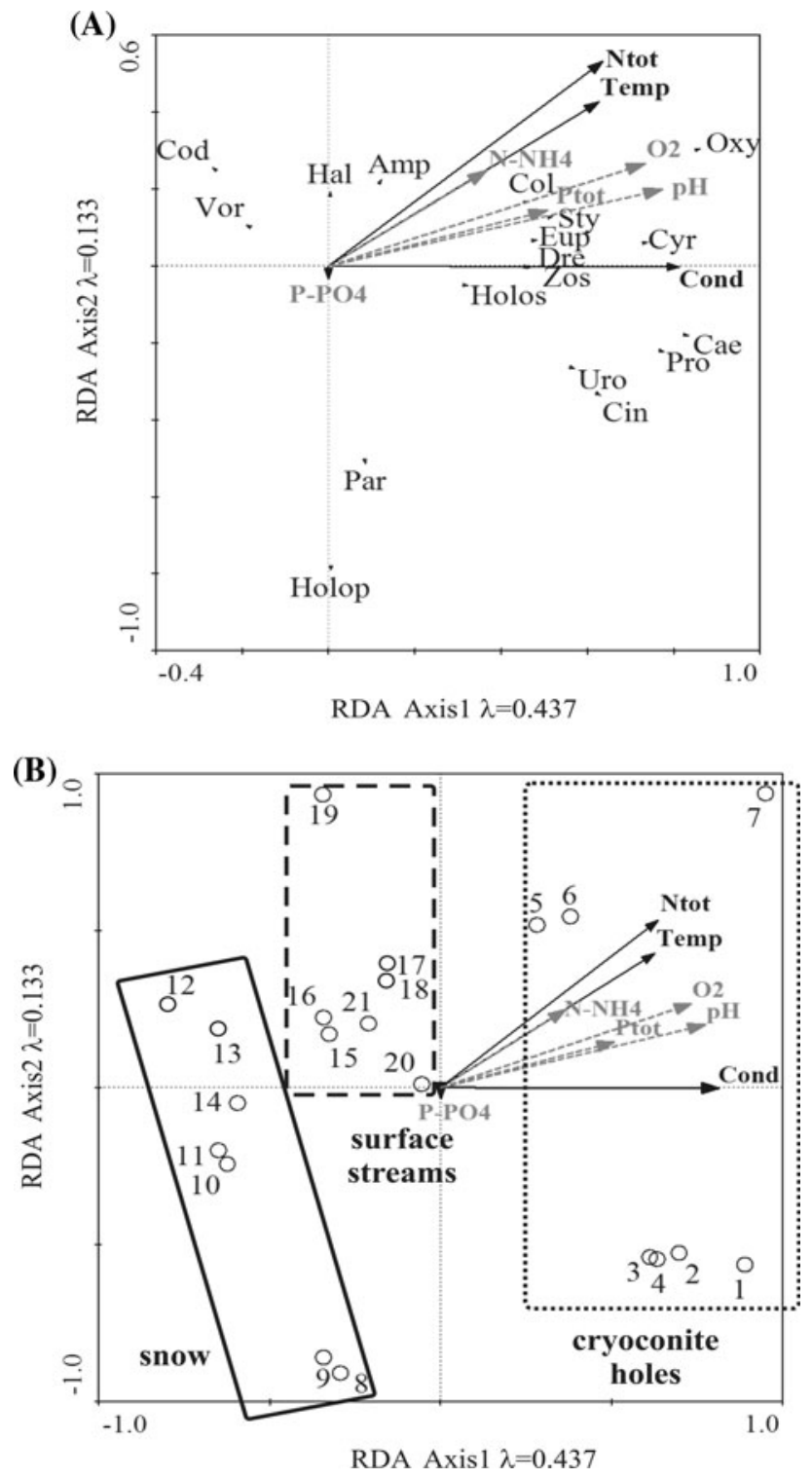

Fig. 6 Biplots of Redundancy Analysis (RDA) of ciliates a species, b samples. Arrows marked as bolded indicate significant parameters in Monte Carlo permutation test at $p<0.05$. Samples collected in studied sites are marked with an Arabic numeral: 1-7 cryoconite holes; 8-14 snow; 15-21 surface streams (Amp-A. pleurosigma, Cyr-Cyrtophorida, Cin-C. margaritaceum, Cod-C. cratera, Col-C. cucullus, Cae-Caenomorpha spp., Dre-Drepanomonas revolute, Eup-Euplotes sp., Hal-Halteria sp., Hol-Holophrya sp., Holos-H. pullaster, Oxy-Oxytricha sp., Par-P. putrinum, ProProrodon sp., Sty-S. mytilus-Komplex, Vor-V. companula, UroUrotricha sp., Zos-Zosterodasys sp.)

variety of species in glacial cryoconite holes in the case of bacterial, eukaryotic, and archaeal communities. In the ciliate assemblage, only two ciliate species constituted common taxa, that is, they occurred in all three microenvironments analyzed. This suggests that the taxonomic composition of ciliates is closely related to specific sites and depends on the physical and chemical parameters of the micro-habitat. Ciliate species identified in this study have also been observed in other polar regions. Halteria sp. and Oxytricha sp. were recorded in cryoconite holes in the Arctic (Säwström et al. 2002), and Colpodea and Oxytricha sp. also occurred in mosses and soil environments in Antarctica (Foissner 1996; Petz 1997; Bamforth et al. 2005). Groups of characteristic (exclusive) ciliates occurring in only one micro-habitat formed a comparatively low number of taxa and also had low frequency and numbers. Four characteristic taxa were identified in cryoconite holes: C. margaritaceum, D. revoluta, Urotricha sp., and Zosterodasys sp. These species have also been observed in ciliate communities in mezo- and eutrophic lakes and have also been encountered in mosses in the upper soil layer (Foissner and Berger 1996; Bamforth 2001; Mieczan 2005). According to some authors (Foissner and Berger 1996), these species occur most commonly in oligo- and beta-mesosaprobic environments. Grolière (1977) studied the occurrence of these species in peat lands in eastern France. Similar to species richness, the number of ciliates was also significantly higher in cryoconite holes compared with surface snow and streams. The abundance of ciliates observed on the Ecology Glacier was higher than that recorded on the Canada Glacier located in the McMurdo Dry Valleys of Antarctica (Mueller and Pollard 2004). Certain physical and chemical properties of water in the glacier had a clear effect on the structure of microorganisms. In the present study, both the numbers and biomass of ciliates decreased in habitats with low concentrations of nutrients (particularly concentrations of total nitrogen) and low conductivity. It seems that an increase in the abundance of microorganisms in the cryoconite holes may be related to more favorable nutritional conditions at these sites. This is supported by a significant correlation between total nitrogen content and ciliate abundance. In addition, nutrients may have an indirect effect on the occurrence of ciliates by controlling the abundance of potential food (particularly bacteria and algae). The significant effect of nutritional conditions is also supported by Zdanowski (personal information), who found that bacterial abundance was approximately 2-3 times higher in the cryoconite holes than in the surface streams. Temperature is another factor likely to substantially influence ciliate succession. According to Finlay (1980), the growth and reproduction of freshwater ciliates were strongly correlated with temperature. On the Ecology Glacier, temperature had a significant influence on the number of ciliates; numbers were significantly higher in the cryoconite holes than in other habitats. Many ciliates occur in waters with a broad temperature range, or are eurythermic, and higher temperature usually causes an abundant growth of ciliates. In this study, ciliate communities were mainly composed of Holophrya sp., Oxytricha sp., Prorodon sp., S. mytilus-Komplex, and 
Caenomorpha spp. Most of these species have been found in lakes of various trophic types, and in ice environments (Foissner 1996; Petz 1997; Bamforth et al. 2005). Species belonging to Prostomatida and Cyrtophorida have also been observed in the pelagic zone of small and large water bodies, occasionally in running waters, and were also commonly found in strongly contaminated waters (Mieczan 2005). Dominance of Colpodea was observed in moss in the Gough and Marion Islands (Foissner 1996). The domination of this order could have resulted from its wide ecological tolerance. In habitats with very low concentrations of nutrients (surface streams), Caenomorpha spp., S. mytilus-Komplex, and $C$. cratera were the most numerous species and were identified as permanent components throughout the study period. Cyrtophorida also contributed to the species found. However, the contribution of Oxytricha sp., Prorodon sp., and Holophrya sp. increased with an increase in the concentration of total nitrogen (cryoconite holes and surface snow). Species of the genera Oxytricha and Holophrya occurred in lakes differing in trophic status. Prorodon generally occurred abundantly in eutrophic waters and were also observed in humic lakes and peat bog ecosystems (Järvinen 1993). The ciliate communities of the habitats studied contained the greatest number of bacterivorous species and the smallest number of algivore ciliates. This suggests that ciliates in glacier ecosystems constitute a significant link in the flow of matter and energy between bacteria and higher invertebrates. Bacterivorous ciliates reached the highest proportion in cryoconite holes, slightly smaller in surface streams, and the smallest in surface snow. In the snow and streams, the proportion of omnivorous species increased. The small proportion of algivorous and algae-diatom feeder ciliates in the habitats studied could have been caused by problems with access to food availability. The dominating algae were filamentous and colonial diatoms, inaccessible or barely accessible for ciliates. The size classes of protozoa clearly differed between individual sites. Medium forms (50-200 $\mu \mathrm{m})$ dominated snow and cryoconite holes, whereas small forms $(<50 \mu \mathrm{m})$ dominated streams. Fenchel (1987) proposed that the size of protozoa was correlated with the size of the food particle preferred. Nanociliates $(<50 \mu \mathrm{m})$ mainly feed on picoalgae and bacteria. Medium-sized ciliates feed on bacteria and small zoo- and phytoflagellates $(<5 \mu \mathrm{m})$, while larger ciliates prefer nanoflagellates from the size fraction 4-10 $\mu \mathrm{m}$. Paffenhöfer (1998) provided further evidence that ciliates ingest particles ranging from $1 / 3$ to $1 / 30$ of their actual diameter. The Ecology Glacier is dominated by nano- and medium-sized ciliates that would prey on picoalgae and bacteria. Similar patterns also occurred in the Pinguii Pond located in Hope Bay in the Maritime Antarctic region (Allende and Pizarro 2006).
Our study revealed the diverse character of the ciliate community of the Ecology Glacier. A total of 18 taxa belonging to 9 genera were identified. Ciliate species richness and abundance decreased in surface snow and streams, and cryoconite holes were generally characterized by higher richness and density of these microorganisms. Our study suggests that ciliates play an important role in the microbial food web in glacier ecosystems. The most common ciliate feeding groups were bacterivores and omnivores. Temperature, conductivity, and total nitrogen concentrations appeared to play a key role in determining the distribution pattern of ciliate communities. Further research is required to explain the impact of biotic factors influencing the presence of ciliates, including the abundance of bacteria, microalgae, and small Metazoa.

Acknowledgments We thank our colleagues Marta Nieckarz and Adam Latusek for their invaluable help and technical assistance during collection of the samples.

Open Access This article is distributed under the terms of the Creative Commons Attribution License which permits any use, distribution, and reproduction in any medium, provided the original author(s) and the source are credited.

\section{References}

Allende L, Pizarro H (2006) Top-down control on plankton components in an Antarctic pond: experimental approach to the study of low-complexity food web. Polar Biol 29:893-901

Anesio AM, Laybourn-Parry J (2012) Glaciers and ice sheets as a biome. Trends Ecol Evol 4:219-225

Anesio AM, Mindl B, Laybourn-Parry J, Hadson AJ, Sattler B (2007) Viral dynamics in cryoconite holes on a high Arctic glacier (Svalbard). J Geogr Res. doi:10.1029/2006JG000350

Anesio AM, Hodson AJ, Fritz A, Psenner R, Sattler B (2009) High microbial activity on glaciers: importance to the global carbon cycle. Glob Change Biol. doi:10.1111/j1365-2486.2008.01758

Augustin H, Foissner W, Adam H (1984) An improved pyridinated silver carbonate method which need few specimens and yields permanent slides of impregnation ciliates (Protozoa, Ciliophora). Mikroskopie 41:134-137

Bamforth SS (2001) Proportions of active ciliate taxa in soils. Biol Fertil Soils 33:197-203

Bamforth SS, Wall DH, Virginia RA (2005) Distribution and diversity of soil protozoa in the McMurdo Dry Valleys of Antarctica. Polar Biol 28:756-762

Bintanja R (1995) The local surface energy balance of the Ecology Glacier, King George Island, Antarctica: measurements and modeling. Antarctic Sci 3:315-325

Birkenmajer K (2002) Retreat of Ecology Glacier, Admirality Bay, King George Island (South Shetland Islands, West Antarctica), 1956-2001. Bull Polish Acad Sci Earth Sci 50:15-29

Cameron KA, Hodson AJ, Osborn AM (2011) Structure and diversity of bacterial, eukaryotic and archaeal communities in glacial cryoconite holes from the Arctic and the Antarctic. FEMS Microbiol Ecol. doi:10.1111/j.1574-6941.2011.01277

Fenchel T (1987) Ecology of protozoa. In: Brock TD (ed) Ecology of protozoa: the biology of free-living phagotrophic protist. Springer, Berlin, pp 197-198 
Fernandez-Galiano D (1994) The ammoniacal silver carbonate method as a general procedure in the study of protozoa from sewage (and other) waters. Water Res 28:495-496

Finlay BJ (1980) Temporal and vertical distribution of ciliophoran communities in the benthos of a small eutrophic loch with particular reference to the redox profile. Freshw Biol 10:15-34

Finlay BJ (1982) Procedures for the isolation, cultivation and identification of protozoa. Exp Microb Ecol 1:44-65

Foissner W (1996) Terrestial ciliates (Protozoa, Ciliophora) from two islands (Gough, Marion) in the southern oceans, with description of two new species, Arcuospathidium cooperi and Oxytricha ottowi. Archiv für Protistenkol 23:282-291

Foissner W, Berger H (1996) A user-friendly guide to the ciliates (Protozoa, Ciliophora) commonly used by hydrobiologists as bioindicators in rivers, lakes and waste waters, with notes on their ecology. Freshw Biol 35:375-470

Gilbert D, Amblard C, Bourdier G, Francez AJ (1998) The microbial loop at the surface of a peatland: structure, functioning and impact of nutrients inputs. Microb Ecol 35:89-93

Golterman HL (1969) Methods for chemical analysis of freshwaters. Blackwell Scientific Publications, Oxford

Grolière CA (1977) Contribution à l'ètude de quelques ciliès des sphaignes: II-Dynamique des populations. Protistol 13: $335-352$

Grongaard A, Pugh PJA, McInnes SJ (1999) Tardigrades and other cryoconite biota on the Greenland Ice Sheet. Zool Anz 228:211-214

Gryziak G (2009) Colonization by mites of glacier-free areas in King George Island, Antarctica. Pesqui Agropecu Bras Brasilia 8:891-895

Järvinen M (1993) Pelagic ciliates in acidified mesohumic forest lake before and after lime addition. Ver Intern Ver Limnol 25: 534-538

Jerome CA, Montagnes DJS, Taylor FJR (1993) The effect of the quantitative protargol stain and Lugols and Buinos fixatives on cell size: a more accurate estimate ciliate species biomass. J Euk Microbiol 40:254-259

Koshima S (1984) A novel cold-tolerant insect found in a Himalayan glacier. Nature 310:225-227

Kovach W (2002) MVSP-Multivariate statistical package. Kovach Computing Services, Anglesey

Laybourn-Parry J, Marchant HJ, Brown P (1991) The plankton of a large oligotrophic freshwater Antarctic lake. J Plankton Res 13:1137-1149

Lee JJ, Small EB, Lynn DH, Bovee EC (1985) Some techniques for collecting, cultivating and observing protozoa. In: Lee JJ, Hutner $\mathrm{SH}$, Bovee EC (eds) An illustrated guide to the protozoa. Society of protozoologists. Allen Press, Lawrence, pp 1-7
Lepš J, Šmilauer P (2003) Multivariate analysis of ecological data using CANOCO. University Press, Cambridge

Martinov V, Rakusa-Suszczewski S (1989) Ten years of climate observations at the Arctowski and Bellingshausen Station (King George Islands, South Shetlands, Antarctis). In: Breymeyer A (ed) Global Change Regional Research Centres: Scientific problems and concept developments, Warsaw, pp 80-90

Mieczan T (2005) Periphytic ciliates in littoral zone of three lakes of different trophic status. Pol J Ecol 53:489-502

Mueller DR, Pollard WH (2004) Gradient analysis of cryoconite ecosystems from two polar glaciers. Polar Biol 27:66-74

Mueller DR, Vincent WF, Pollard WH, Fristen CH (2001) Glacial cryoconite ecosystems: a bipolar comparison of algal communities and habitats. Nov Hedvig Beih 123:173-197

Nijssen D, Rousseau R, Van Hecke P (1998) The Lorenz curve: a graphical representation of evenness. Coenoses 13:33-38

Oerlemans J (1986) Glaciers as indicators of carbon dioxide warming. Nature 320:607-609

Paffenhöfer GA (1998) Heterotrophic protozoa and small metazoa: feeding rates and prey-consumer interactions. J Plankton Res 20:121-133

Petz W (1997) Ecology of the active soil microfauna (Protozoa, Metazoa) of Wilkes Land, East Antarctica. Polar Biol 18:33-44

Pierce RW, Turner JT (1992) Ecology of plankton ciliates in marine food webs. Rev Aquat Sci 6:139-181

Porazinska DL, Fountain AG, Nylen TH, Tranter M, Virginia RA, Wall DH (2004) The biodiversity and biogeochemistry of cryoconite holes from McMurdo Dry Valley glaciers, Antarctica. Arct Antarct Alp Res 36:84-91

Roberts EC, Priscu JC, Wolf C, Lyons B, Laybourn-Parry J (2004) The distribution of microplankton in the McMurdo Dry Valley Lakes, Antarctica: response to ecosystem legacy or present-day climatic control? Polar Biol 27:238-249

SAS Institute Inc (2001) SAS users guide. Version 8.2 Edition, SA Cary

Säwström C, Mumford P, Marshall W, Hadson A, Laybourn-Parry J (2002) The microbial communities and primary productivity of cryoconite holes in Arctic glacier (Svalbard $79^{\circ} \mathrm{N}$ ). Polar Biol 25:591-596

Ter Braak CJF (1988-1992) CANOCO-FORTRAN program for Canonical Community Ordination (version 2.1). Microcomputer Power 96. Ithaca, New York

Utermölh H (1958) Zur vervollkommnung der quantative phytoplankton-methodik. Mitt Int Ver Limnol 9:1-38

Wharton RA, Vinyard WC, Parker BC, Simmons GM, Seaburg KG (1981) Algae in cryoconite holes on the Canada Glacier in southern Victoria Land, Antarctica. Phycologia 20:208-211 